\title{
GMR
}

\section{Selection of reference genes in canine uterine}

\section{tissues}

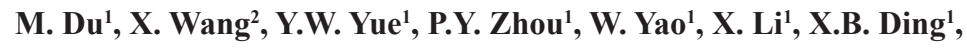 \\ X.F. Liu ${ }^{1}$, H. Guo ${ }^{1}$ and W.Z. Ma ${ }^{1}$ \\ ${ }^{1}$ Laboratory of Agricultural Animal Genetics and Breeding, \\ College of Animal Science and Veterinary Medicine, \\ Tianjin Agricultural University, Tianjin, China \\ ${ }^{2}$ Department of Foreign Language, Foreign Linguistics and Applied Linguistics, \\ Jiangsu Normal University, Xuzhou, China \\ Corresponding author: W.Z. Ma \\ E-mail: 13821734150@163.com
}

Genet. Mol. Res. 15 (2): gmr. 15028138

Received November 25, 2015

Accepted January 18, 2016

Published June 17, 2016

DOI http://dx.doi.org/10.4238/gmr.15028138

\begin{abstract}
Real-time quantitative polymerase chain reaction (RTqPCR) is usually employed in gene expression studies in veterinary research, including in studies on canine pyometra. Canine pyometra is a common clinical disease in bitches. When using RT-qPCR, internal standards, such as reference genes, are necessary to investigate relative gene expression by quantitative measurements of mRNA levels. The aim of this study was to evaluate the stability of reference genes and select reference genes suitable for canine pyometra studies. We collected 24 bitch uterine tissue samples, including five healthy and 19 pyometra infected samples. These were used to screen the best reference genes of seven candidate genes (18SrRNA, ACTB, B2M, GAPDH, HPRT, RPL13A, and YWHAZ). The method of KH Sadek and the GeNorm, Normfinder, BestKeeper, and RefFinder software were used to evaluate the stability of gene expression in both pyometra and healthy uterine samples. The results showed that the expression
\end{abstract}


stability of the candidate gene in pyometra and healthy tissues differed. We showed that YWHAZ was the best reference gene, which could be used as an accurate internal control gene in canine pyometra studies. To further validate this recommendation, the expression profile of a target gene insulin-like growth factor 1 receptor gene (IGF1R) was investigated. We found that the expression of IGF1R was significantly altered when different reference genes were used. All reference genes identified in the present study will enable more accurate normalization of gene expression data in both pyometra infected and healthy uterine tissues.

Key words: Real-time quantitative PCR; Pyometra; Reference genes; IGF1R; Gene expression

\section{INTRODUCTION}

Canine pyometra is a common disease in bitches, which is usually diagnosed from four weeks to four months after estrus in sexually mature bitches (Niskanen and Thrusfield, 1998). This disease is thought to be the result of bacterial and hormonal interactions (Hardy, 1980; Arthur et al., 1989). Hormonal factors often cause only subtle changes, therefore, the diagnosis often occurs after the onset of the clinical symptoms (Miller-Liebl et al., 1994). Although the exact etiology is unknown, a repeated and prolonged response to estrogen would lead to hormonally mediated changes in the uterine tissues (Smith, 2006). Cystic endometrial hyperplasia (CEH) pyometra is a classic concept introduced by Dow (1959). It is thought that CEH may predispose bitches to develop pyometra (Fransson and Ragle, 2003). Based on previous studies, it appears that several growth factors, which cooperate with the sex steroid hormones, might play an important role in the pathogenesis of CEH. Insulin-like growth factor-1 (IGF-1) is one of the most important growth factors known to have a potential mitogenic effect on the uterus (Murphy et al., 1987; Murphy and Ghahary, 1990; Frost et al., 1993; Giudice, 1994; Giudice et al., 1998). IGF-1 exerts its effects at the cellular level, by interacting with the type-I IGF receptor. In this study, we therefore used IGF 1 receptor (IGF $1 \mathrm{R})$ as the target gene.

Real-time quantitative polymerase chain reaction (RT-qPCR) is an accurate, rapid, and sensitive technique used to assess gene expression (Kubista et al., 2006). Recently, it has been discussed how to normalize this method (Andersen et al., 2004; Dheda et al., 2004; Meller et al., 2005; Rubie et al., 2005; Zhang et al., 2005). The most frequently applied normalization method is the use of internal reference genes (Nelissen et al., 2010). The reference genes are selected depending on their adequate expression in the target tissue (Sadek et al., 2012). However, some commonly used reference genes, like glyceraldehyde-3phosphate dehydrogenase (GAPDH) and beta-actin (ACTB), have been shown to have variable expression patterns. Therefore, they may not be suitable for normalizing RT-qPCR data under certain conditions (Zhong and Simons, 1999; Stürzenbaum and Kille, 2001; Glare et al., 2002; Bas et al., 2004; Olsvik et al., 2005). Thus, it is recommended that an experimental validation of reference gene expression stability should be carried out for each target tissue and disease (Bustin and Mueller, 2005; Hruz et al., 2011).

So far, there is no published data about the stability of candidate reference genes for pyometra. In this study, we investigated the expression of seven common reference genes, 
including 18S ribosomal RNA (18SrRNA), (ACTB), beta2-microglobulin (B2M), (GAPDH), hypoxanthine phosphoribosyl-transferase1 (HPRT), ribosomal protein L13a (RPL13A), and tyrosine 3-mono-oxygenase/tryptophan 5-monooxygenase activation protein and zeta polypeptide (YWHAZ), in healthy and pyometra infected bitches. To evaluate our results, we then investigated the IGF I R expression profile, using different candidate reference genes. It is important to have an understanding of differential gene expression between pyometra infected and healthy tissues, to identify disease biomarkers. This may help to diagnose pyometra at earlier stages and contribute to reducing bitch mortality or morbidity.

\section{MATERIAL AND METHODS}

\section{Tissue acquisition}

Canine uterine tissue was obtained from bitches that had undergone total ovariohysterectomy in the hospital of Tianjin Agricultural University. Samples from five healthy and 19 pyometra infected bitches were immediately frozen in liquid nitrogen and transferred to the laboratory, where they were maintained at $-80^{\circ} \mathrm{C}$ until subsequent analysis.

\section{Selection of reference genes and primer design}

Based on the classes and functions of the genes that had already been used as reference genes in dog and human tissues, we selected 18SrRNA, ACTB, B2M, GAPDH, HPRT, RPL13A, and YWHAZ as candidate reference genes, to detect the expression stability in both healthy and pyometra samples. The IGF1R gene was selected to confirm the necessity of our study. The nucleotide sequences of all genes were obtained from GenBank (www.ncbi.nih.gov/genbank/ index.html). Primer design was performed with Primer 5.0 (http://www. premierbiosoft.com) and Primer BLAST (Ye et al., 2012). Information about the primers used is shown in Table 1.

\section{Total RNA isolation and RT-qPCR}

Following the manufacturer protocol (Invitrogen, New York, NY, USA), Trizol was used to extract total RNA from the tissue samples. The integrity and purity of the RNA was analyzed using a NanoDrop ND-1000 spectrophotometer (Thermo Fisher Scientific, Waltham, MA, USA). All-in-One ${ }^{\mathrm{TM}}$ First-Strand cDNA Synthesis Kit (GeneCopoeia, Rockville, MD, USA) was used to transcribe $1 \mathrm{mg}$ of each total RNA sample into cDNA, following the manufacturer protocol. The RT-qPCR was performed in triplicate according to the manufacturer protocol on a Bio-Rad CFX-96 real-time PCR system (Bio-Rad, USA). The reactions contained $10 \mu \mathrm{L} 2 \mathrm{X}$ All-in-One ${ }^{\mathrm{TM}} \mathrm{qPCR}$ Mix, $0.2 \mu \mathrm{M}$ reference gene primer mix, $1 \mu \mathrm{L} \mathrm{cDNA}$, and $5 \mu \mathrm{L}$ double distilled water, adding up to a total reaction volume of $25 \mu \mathrm{L}$. First, we used optimized cycling conditions of $95^{\circ} \mathrm{C}$ for $10 \mathrm{~min}$ for the initial cDNA denaturation, followed by 40 cycles of template denaturation steps at $95^{\circ} \mathrm{C}$ for $15 \mathrm{~s}$. Finally, a $20 \mathrm{~s}$ annealing at the mean melting temperature of each gene (shown in Table 1) followed by extension at $72^{\circ} \mathrm{C}$ for $15 \mathrm{~s}$.

\section{Expression stability analysis of candidate reference genes}

The stability of the candidate reference genes was evaluated using the method of 
KH Sadek and colleagues (Sadek et al., 2012) and the GeNorm (Vandesompele et al., 2002), Normfinder (Andersen et al., 2004), BestKeeper (Pfaffl et al., 2004), and RefFinder (Xie et al., 2011) algorithms. The method of Sadek et al. (2012) is an approach that depends on comparing the changes in cycle threshold values $\left(\mathrm{C}_{t}\right)$ of all reference genes within different groups. A MannWhitney U-test was conducted for statistical analysis using SPSS 2000 (SPSS, Inc., Chicago, IL, USA). The GeNorm tool was used to calculate stability measures (M) of the internal control genes for each gene and the optimal number of genes (two or more) required for reliable normalisation of real-time PCR data is calculated by calculating the pairwise variation (V) of sequential normalisation factors obtained from the inclusion of additional control genes (proposed cut-off value $\mathrm{V}=0.15$ ) According to the expression stability of the candidate reference genes in a given sample set, Normfinder ranks the set of candidate normalization genes. The BestKeeper software mainly measures the stability of the internal gene using a pairwise correlation analysis of all reference genes and calculates the geometric mean of the most suitable genes. Lastly, RefFinder was used to allocate an appropriate proportion of a single gene, the geometric average weights were calculated, and, finally, ranked.

\section{Validation of reference gene selection}

To test the validation of the selected seven internal genes, relative expression of IGF1R was calculated using the $2^{-\triangle \mathrm{Ct}}$ method. The average of the linearized values $\left(2^{-\mathrm{ACt}}\right)$ of the healthy (control) group was used as the calibrator. Statistical differences between the pyometra and control groups were evaluated by the Tukey test. In all cases, a statistical significance level of $\mathrm{P} \leq 0.05$ was used.

\section{RESULTS}

\section{Bitch characteristics}

In this study, the incidence of pyometra was $89.3 \%$ in bitches that were more than four years old, which is higher than that found by Fukuda (2001). The average age for this disease cohort was 8.03 years, which was younger than in Fukuda (2001)'s study. The average age in the control group was five years old.

\section{RNA integrity and primer specificity}

Each primer pair amplified a single specific amplicon, as shown by $1.5 \%$ agarose gel electrophoresis and melting curve analysis (data not shown). To obtain the PCR efficiency and correlation coefficient, we used gradient dilution of pooled cDNA $\left(1 \mathrm{X}, 10 \mathrm{X}, 10^{2} \mathrm{X}, 10^{3} \mathrm{X}\right.$, and $\left.10^{4} \mathrm{X}\right)$ to draw a standard curve for each gene. The equation was as follows: Efficiency $(E)(\%)=(A-1) \times 100$, where $\left.A=10^{[-1 / 1 / s p e ~ o f ~ s t a n d a r d ~ c u r v e ~}\right]$. Primer amplification efficiency of all genes ranged from $90.5 \%$ to $112.2 \%$, indicating that all primers worked successfully. The RNA absorbance ratio at 260/280 ranged from 1.9 to 2.0 (data not shown), which indicates that the quality of the mRNA met the requirements of the subsequent tests (Table 1). In order to explore whether there was genomic DNA contamination, template mRNA that contained molecular grade water without template controls (NTC) was tested for each reaction. No product was synthesized in the NTC, which confirms the absence of DNA contamination. 
Table 1. Name, function and product length, mean melting temperature (Tm), and sequence primers for candidate reference genes for normalizing gene expression.

\begin{tabular}{|c|c|c|c|c|c|c|c|}
\hline Symbol & Gene name & Function & GenBank No. & Primer sequence & \begin{tabular}{|c|} 
Product \\
length (bp)
\end{tabular} & $\begin{array}{c}\text { Mean } \\
\operatorname{Tm}\left({ }^{\circ} \mathrm{C}\right)\end{array}$ & $\begin{array}{c}\text { Efficiency } \\
(\%)\end{array}$ \\
\hline$\overline{18 \mathrm{srRNA}}$ & 18S ribosomal RNA & \begin{tabular}{|l} 
Ribosome subunit \\
\end{tabular} & AY623831 & $\begin{array}{l}\text { Forward: AGAAACGGCTACCACATCC } \\
\text { Reverse: CACCAGACTTGCCCTCCA }\end{array}$ & 173 & 58 & 108.9 \\
\hline$\overline{\mathrm{ACTB}}$ & $\beta$-actin & \begin{tabular}{|l|l} 
Cytoskeletal structural protein \\
\end{tabular} & NM_001195845 & $\begin{array}{l}\text { Forward: CCATCTTGCGTCTGGACCT } \\
\text { Reverse: GCCATCTCCTGCTCGAAGT }\end{array}$ & 162 & 60 & 104.2 \\
\hline$\overline{\mathrm{B} 2 \mathrm{M}}$ & $\beta$-2-microglobulin & Component of MHC-I & XM535458 & $\begin{array}{l}\text { Forward: ACGACACCCAGCAGAGAATG } \\
\text { Reverse: CATCCTGCTCATTGGGAGTGA }\end{array}$ & 194 & 57 & 90.5 \\
\hline$\overline{\text { GAPDH }}$ & $\begin{array}{l}\text { Glyceraldehyde 3-phosphate } \\
\text { Dehydrogenase }\end{array}$ & \begin{tabular}{|l} 
Glycolysis and gluconeogenesis \\
\end{tabular} & AF327898 & $\begin{array}{l}\text { Forward: GATCCCGCCAACATCAAA } \\
\text { Reverse: GCATCAGCAGAAGGAGCAG }\end{array}$ & 128 & 57 & 108.0 \\
\hline $\begin{array}{l}\text { HPRT } \\
\end{array}$ & Hypoxanthine ribosyltransferase & Metabolic salvage of purines & AY283372 & $\begin{array}{l}\text { Forward: GTTGACTGGTCATTACAGTAGCTC } \\
\text { Reverse: GGGAGGCCATCACATCGTAG }\end{array}$ & 162 & 59 & 108.4 \\
\hline RPL13A & Ribosomal protein L13a & $\begin{array}{l}\begin{array}{l}\text { Component of } 60 \text { S ribosomal } \\
\text { subunit }\end{array} \\
\end{array}$ & XM_003432726 & $\begin{array}{l}\text { Forward: CGAAGATGGCGGAGGGG } \\
\text { Reverse: GTTGGTGTTCATCCGCTTGC }\end{array}$ & 200 & 59 & 95.0 \\
\hline $\begin{array}{l}\text { YWHAZ } \\
\text { IGF-IR }\end{array}$ & $\begin{array}{l}\text { Tyrosine3-monooxygenase/tryptophan } \\
\text { 5-monooxygenase activation protein, } \\
\text { zeta polypeptide } \\
\text { Insulin-like growth factor-I receptor }\end{array}$ & \begin{tabular}{|l|} 
Mediator of signal transduction \\
\end{tabular} & $\begin{array}{l}\text { XM533072 } \\
\text { XM545828.4 }\end{array}$ & $\begin{array}{l}\text { Forward: CTGGTGCAGAAGGCCAAACT } \\
\text { Reverse: AAGATGACCTACGGGCTCCT } \\
\text { Forward: CATCCGTGGGGCTAAGAGTG } \\
\text { Reverse: AACTGAGGTTACCGTTGGGCC }\end{array}$ & $\begin{array}{l}160 \\
151\end{array}$ & $\begin{array}{l}57 \\
58\end{array}$ & $\begin{array}{l}95.0 \\
96.8\end{array}$ \\
\hline
\end{tabular}

\section{Analysis of the Sadek et al. (2012) method}

The difference between two $\mathrm{C}_{\mathrm{t}}$ values is denoted as $\Delta \mathrm{C}_{\mathrm{t}}$. Table 2 shows the average $\Delta \mathrm{C}_{\mathrm{t}}$ for each candidate reference gene between the control healthy and pyometra groups. The $\Delta \mathrm{C}_{\mathrm{t}}$ data are reported as means $\pm \mathrm{SD}$. These results indicate that the change between the control to pyometra groups was largest in RPL13A. Further examination of the variation in the $\mathrm{C}_{t}$ values of each reference gene in the different groups are shown in Figure 1. The RPL13A demonstrated lower gene expression levels in the uterine tissues of the pyometra compared to the control group.

Table 2. Mean change in $\Delta \mathrm{Ct}$ values (mean $\Delta \mathrm{Ct}$ ) of individual reference gene expression within the pyometra and control endometria.

\begin{tabular}{l|c|c|c|c|c|c|c}
\hline & 18SrRNA & ACTB & B2M & GAPDH & HPRT & RPL13A & YWHAZ \\
\hline Mean $\Delta \mathrm{Ct}$ & $0.567 \pm 3.76$ & $0.835 \pm 2.14$ & $0.122 \pm 4.50$ & $0.118 \pm 0.36$ & $-0.876 \pm 5.29$ & $2.810 \pm 3.73$ & $0.808 \pm 1.84$ \\
\hline
\end{tabular}

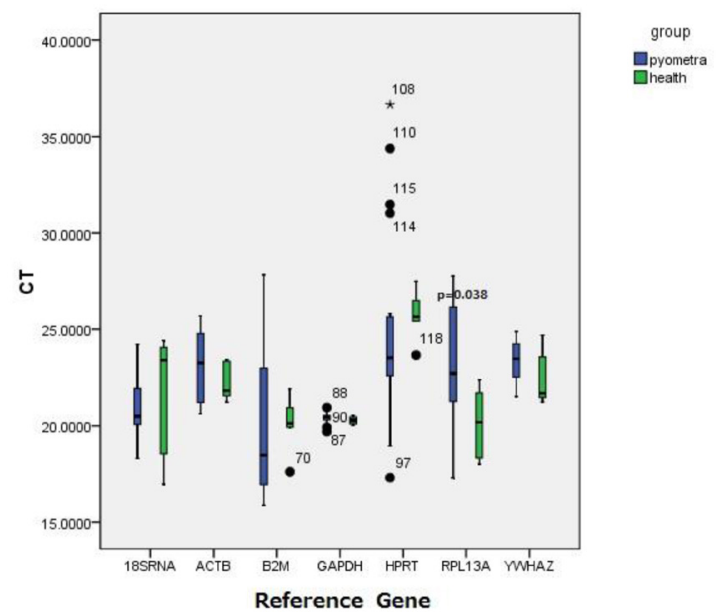

Figure 1. Ct values calculated from raw RT-qPCR output for the 7 reference gene candidates in Pyometra and healthy group. Fifty percent of the values are included in the box. The median is represented by the line in the box. The interquartile range is bordered by the upper and lower edges, which indicate the 75 th and 25 th percentiles, respectively. 


\section{GeNorm analysis}

The results from GeNorm revealed that the candidate genes displayed a wide range of expression levels in the uterine tissues when comparing the control and pyometra groups. Only YWHAZ displayed stability in the uterine tissues across both groups. The results illustrated that the $\mathrm{M}$ values for all genes were lower than 1.5; the values for each of the reference genes are shown in Table 3. The most stable reference genes in the uterine tissues taken from the pyometra group were GAPDH, YWHAZ, and 18SRNA (M values; $0.173,0.174$, and 0.216, respectively; Figure 2A and Table 3). In the uterine tissue from the control bitches, the most stable reference genes were ACTB, YWHAZ, and HPRT (M values; 0.110, 0.115, and 0.104, respectively; Figure 2B and Table 3). When the uterine tissues from both control and pyometra groups were regarded together, the three most suitable reference genes were GAPDH, YWHAZ, and ACTB (M values: 0.172, 0.169, and 0.152, respectively; Figure 2C and Table 2). The cutoff threshold that GeNorm uses is 0.15 . At values below this threshold, inclusion of additional reference genes is considered unnecessary. The pairwise variation analysis indicated that for uterine tissue from the pyometra group, the optimal number of reference genes was two (V2 / 3 value $=0.031)($ Figure 3A). The optimal normalization factor was calculated as the geometric mean of the reference genes GAPDH and YWHAZ. For healthy uterine tissues, the optimal number of reference targets was also found to be two $(\mathrm{V} 2 / 3$ value $=0.028)$ (Figure $3 \mathrm{~B})$. The optimal normalization factor was determined as the mean of the reference genes ACTB and YWHAZ. The pairwise variation analysis data indicated that, for uterine tissue from both groups, the optimal number of reference genes was two (V2 / 3 value $=0.028$ ) (Figure 3C), and the optimal normalization factor was calculated as the geometric mean of the reference genes GAPDH and YWHAZ.

Table 3. Expression levels and geNorm stability of reference gene tested in Pyometra (M1), control (M2) and both group (M3) endometrium.

\begin{tabular}{l|c|c|c}
\hline & M1 & M2 & M3 \\
\hline 18SrRNA & 0.216 & 0.238 & 0.223 \\
\hline ACTB & 0.158 & 0.110 & 0.152 \\
\hline B2M & 0.242 & 0.121 & 0.224 \\
\hline GAPDH & 0.173 & 0.135 & 0.172 \\
\hline HPRT & 0.246 & 0.104 & 0.230 \\
\hline RPL13A & 0.191 & 0.147 & 0.197 \\
\hline YWHAZ & 0.174 & 0.115 & 0.169
\end{tabular}

\section{Normfinder analysis}

According to the Normfinder analyses, ACTB, GAPDH, YWHAZ, and RPL13A were the most stable reference genes in all samples. In Normfinder, the results from the RT-qPCR were used to analyze the stability of internal candidate gene expression by variance analysis. Although the exact order was not identical, the obtained rank was similar to that obtained using GeNorm. The ranking of the reference genes, based on their stability values of both groups, was as follows (starting from the most stable to the least stable): pyometra group: ACTB $>$ RPL13A $>$ GAPDH $>$ YWHAZ $>18$ SrRNA > B2M > HPRT; control group: HPRT $>$ ACTB $>$ YWHAZ $>$ B2M $>$ GAPDH $>$ RPL13A > 18SrRNA; and both groups: ACTB > YWHAZ $>$ GAPDH $>$ RPL13A $>$ B2M $>18$ SrRNA $>$ HPRT (Table 4). 

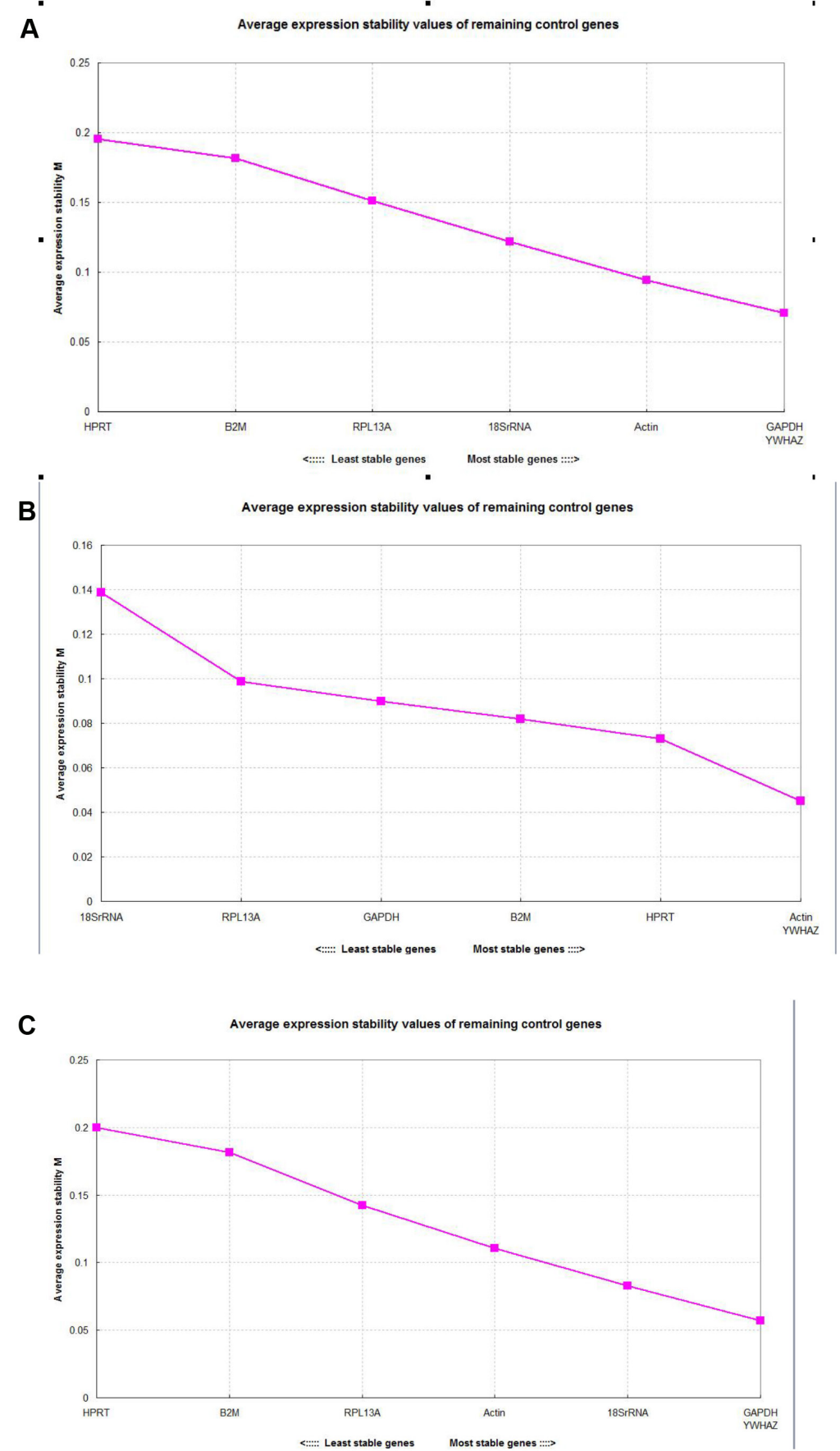

Figure 2. Stability ranking of HKG tested from Pyometra (A), control (B) and both $(\mathbf{C})$ endometrium. The expression stability value (M-value) was determined using the geNorm program. Genes are ranked left to right in order of increasing expression stability, indicated by lower $\mathrm{M}$ values. 
A

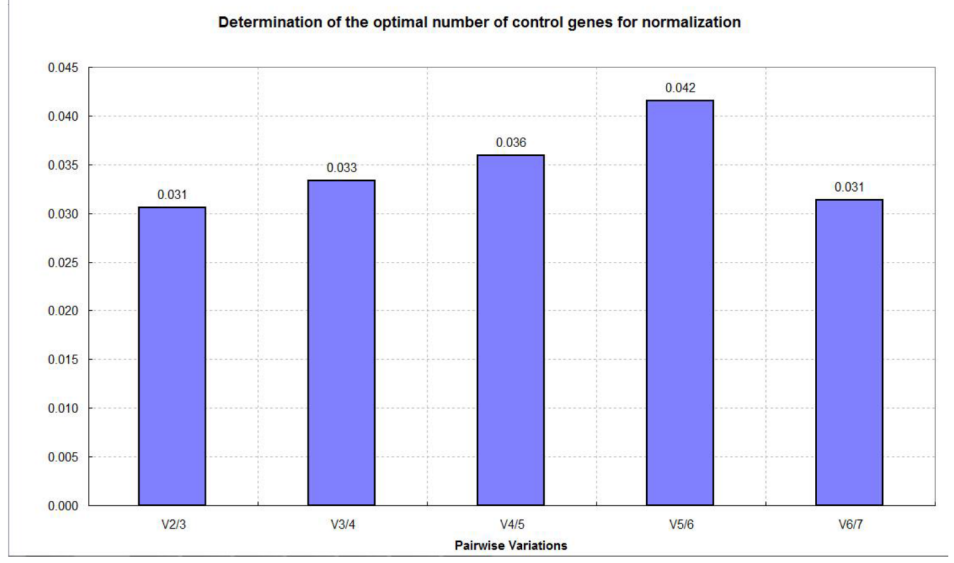

B

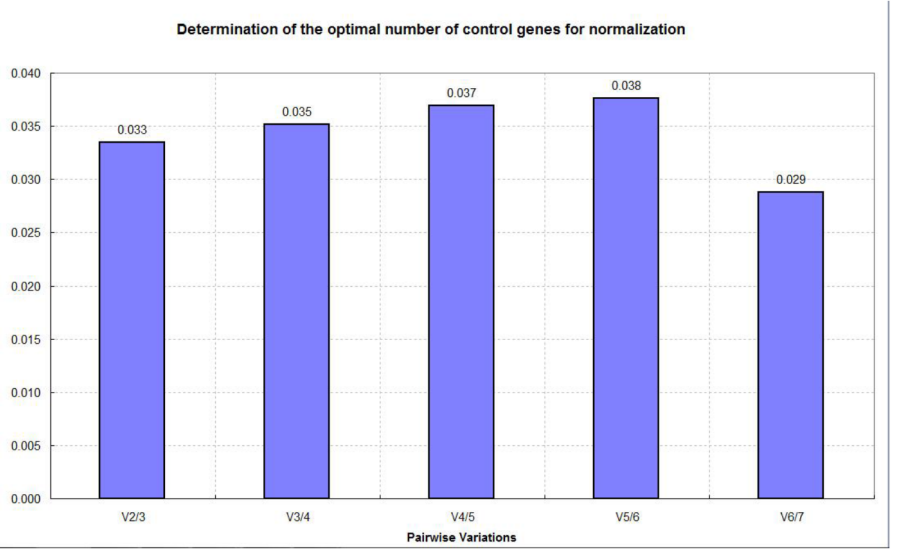

C

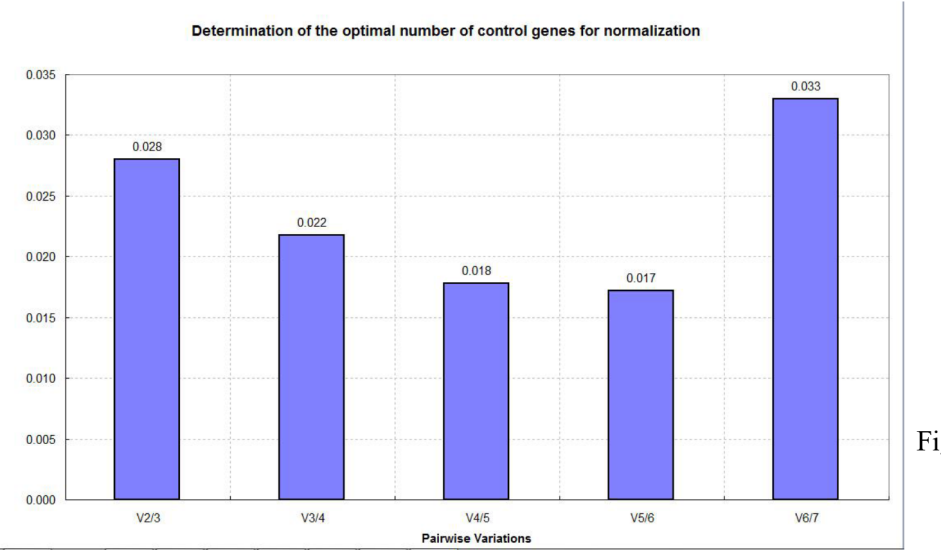

Figure 3. Determination of the optimal number of reference genes for normalization in the endometrium $(N=7)$ based on their pairwise variation (V) analysis using the geNorm algorithm. 
Table 4. Expression of reference genes in endometrium using the NormFinder (stability value) algorithms. Lower stability value indicates more stable expression and vice versa.

\begin{tabular}{l|c|c|c}
\hline & Stability value 1 & Stability value 2 & Stability value 3 \\
\hline 18SrRNA & 0.131 & 0.159 & 0.134 \\
\hline ACTB & 0.040 & 0.020 & 0.036 \\
\hline B2M & 0.144 & 0.049 & 0.129 \\
\hline GAPDH & 0.080 & 0.065 & 0.075 \\
\hline HPRT & 0.147 & 0.019 & 0.134 \\
\hline RPL13A & 0.078 & 0.085 & 0.093 \\
\hline YWHAZ & 0.081 & 0.029 & 0.073 \\
\hline
\end{tabular}

\section{BestKeeper analysis}

The BestKeeper software depends on two criteria to deduce suitable reference genes; the standard deviation (SD) and coefficient of variation (CV). Based on BestKeeper, we found that the most stable genes, in both the control and pyometra group, were GAPDH and YWHAZ. The results of the evaluation of the reference gene by BestKeeper are shown in Table 5 .

Table 5. Expression of most stable reference genes based on BestKeeper.

\begin{tabular}{|c|c|c|c|c|c|c|c|}
\hline & 18SrRNA & ACTB & $\mathrm{B} 2 \mathrm{M}$ & GAPDH & HPRT & RPL13A & YWHAZ \\
\hline $\mathrm{N}$ & 24 & 24 & 24 & 24 & 24 & 24 & 24 \\
\hline geo Mean [CP] & 20.94 & 22.87 & 19.89 & 20.37 & 24.68 & 22.14 & 23.14 \\
\hline ar Mean $[\mathrm{CP}]$ & 21.03 & 22.93 & 20.20 & 20.37 & 25.05 & 22.35 & 23.17 \\
\hline $\min [\mathrm{CP}]$ & 16.96 & 20.61 & 15.87 & 19.69 & 17.30 & 17.30 & 21.24 \\
\hline $\max [\mathrm{CP}]$ & 24.43 & 25.69 & 27.83 & 20.94 & 36.65 & 27.76 & 24.88 \\
\hline std dev $[ \pm \mathrm{CP}]$ & 1.58 & 1.52 & 3.00 & 0.21 & 3.28 & 2.48 & 0.99 \\
\hline $\mathrm{CV}[\% \mathrm{CP}]$ & 7.53 & 6.65 & 14.86 & 1.03 & 13.11 & 11.11 & 4.28 \\
\hline $\min [\mathrm{x}-$ fold $]$ & -15.85 & -4.79 & -16.18 & -1.60 & -165.76 & -28.47 & -3.74 \\
\hline $\max [\mathrm{x}$-fold] & 11.23 & 7.05 & 246.69 & 1.49 & 4033.89 & 49.25 & 3.34 \\
\hline std dev [ $\pm \mathrm{x}$-fold $]$ & 3.00 & 2.88 & 8.00 & 1.16 & 9.73 & 5.59 & 1.99 \\
\hline
\end{tabular}

\section{RefFinder analysis}

We found significant differences in the ranking patterns of the reference genes obtained from the different software programs (GeNorm, Normfinder, and BestKeeper; Tables 3-5). Through RefFinder's comprehensive evaluation of the results produced by the three analysis methods, we were able to avoid the potential one-sidedness of any one analysis method; we used RefFinder, which accommodated all the logarithms to provide a comprehensive ranking for the final stability of the seven target genes. According to RefFinder, YWHAZ was the most stable gene, whereas HPRT was the least stable. The latter would therefore not be recommended for use in normalization (Figure 4).

\section{Expression of IGF1R relative to different internal candidate genes}

In this study, we used different reference genes as internal controls, to measure the relative expression of IGF1R mRNA in the uterine tissues samples. Our results indicated that IGF1R mRNA appeared to be up-regulated in pyometra compared with healthy control uterine tissues when two reference genes (GAPDH and YWHAZ) were used (Figure 5). No significant differences were found in IGF1R mRNA, when the other reference genes were used. These data suggest that different internal reference genes have great influence on the relative expression of the target gene. 
Comprehensive gene stability

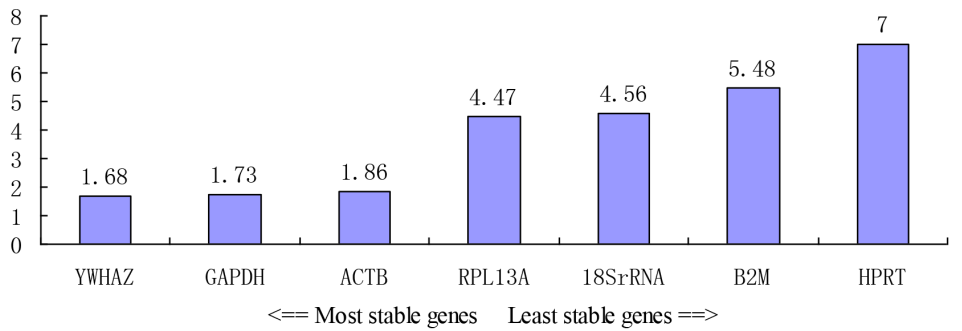

Figure 4. Expression stability value was determined using the RefFinder program.

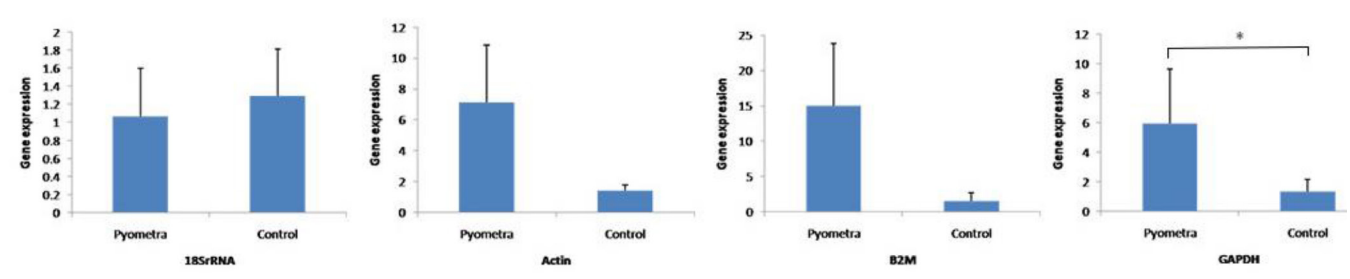

Figure 5. Relative quantification of IGF1R expression in endometria. $* \mathrm{P}<0.05 ; * * \mathrm{P}<0.01$.

\section{DISCUSSION}

In the study of animal diseases, RT-qPCR is one of the most sensitive and reproducible quantification methods for gene expression analysis. Because of the high sensitivity and specificity of this technique, small variations in input quality and quantity can have extreme effects on data interpretation. It is especially important in the case of the internal reference genes to correct and standardize the target gene expression. Even the most stable reference genes vary between organs and species, as shown in previously (van Rijn et al., 2012). The best reference genes are expected to show stable expression under all experimental conditions and detected tissues. However, it has been clearly demonstrated that the ideal reference gene that is stably expressed during all experimental conditions does not exist (Lallemant et al., 2009; CankorurCetinkaya et al., 2012). To date, previous studies involved in choosing reliable reference genes for qRT-PCR normalization have already been conducted in the canine (Brinkhof et al., 2006). However, there are no reports on reference genes selected for use in uterine tissues neither of healthy nor pyometra infected bitches. Therefore, it is generally suggested that reference genes need to be validated for each species and for each specific experimental condition. This study was performed to determine suitable candidate internal reference genes for RT-qPCR analysis in two different types of uterine tissues.

We used the methods of Sadek et al. (2012), GeNorm, Normfinder, BestKeeper, and RefFinder, to determine the most stable endogenous reference genes. Our findings from the different software and methods were consistent with recent studies that have indicated that both the experimental conditions and the presence of pathology could impact the expression of commonly used internal controls. Based on our results, particularly from the GeNorm ranking, YWHAZ and GAPDH were the most reliable reference genes among the seven candidate genes analyzed. The results from pairwise variation analysis, suggested that two of these 
reference genes are best for analysis of relative expression in healthy and pyometra uterine tissues. Based on the results from the comprehensive analysis by Normfinder, ACTB and YWHAZ were the best reference genes. As a final step, we used RefFinder to analyze all data together by integrating three algorithms (GeNorm, Normfinder, and BestKeeper). Using this method, we found that YWHAZ was the most stable reference gene.

Ayers and colleagues showed that the optimal reference genes for comparing gene expression data between normal and diseased infrapatellar fat pad, were RPL13A and YWHAZ (Ayers et al., 2007). In another study, YWHAZ was also found to be one of the most stable reference genes in the combined group (van Rijn et al., 2014). It was also shown that YWHAZ was one of the most stable reference genes common to their syudys (Sadek et al., 2012. This is similar to the results found in the present study. Several studies on reference gene selection for canines have been conducted. Ribosomal protein S19, ribosomal protein S5, B2M, and HPRT have been suggested to be the most appropriate reference genes for dog material (Brinkhof et al., 2006). An interesting result that was found in the present study was that the RPL13A was down-regulated in pyometra compared with control uterine tissue. RPL13A is a protein that belongs to the L13P family of ribosomal proteins, ribosomes are the organelles that catalyze protein synthesis (Olvera et al., 1994). For this reason, RPL13A are considered as indicators for detecting cell vigor levels. After the onset of pyometra, the vigor levels of uterine tissues cells would drop, resulting in a predicted reduction in RPL13A expression. This result may have an important guidance purpose for future studies.

Prominent variation in gene expression in the uterine tissues of pyometra has been reported before, and may be held responsible for the physiological and pathological processes of this disease (Hagman et al., 2009). In our study, we found that the HPRT was not suitable as a reference gene in pyometra or control tissues. Surprisingly, HPRT was the reference gene used by Hagman et al. (2009). It is possible that the choice of reference gene could have contributed to the differences in results obtained by our group and Hagman et al. (2009).

The IGF1R expression suggested that the results may be very different, when different reference genes are used. Moreover, compared to the control group, the mean immunohistochemical score for IGF1R was higher in the pyometra group (M. Du, Y.W. Yue and W.Z. Ma, unpublished results). The results of our analysis indicated that, depending on the selected reference gene, the relative IGF1R mRNA expression appeared upregulated when using YWHAZ and GAPDH as reference genes. However, a limitation of our study and of pyometra research in general, is the use of disease-free uterine tissues samples as controls and the fact that the canine breed is not uniform since the samples came from domestic canine. Nonetheless, obtaining uterine tissue samples from normal bitches with an average age of 8 years are rare in contemporary practice. Despite these limitations, the results clearly demonstrate that most reference genes were not suitable for normalizing RT-qPCR data under these conditions. It is possible that different supra-physiological conditions may alter the stability of reference genes, such as pyometra or pregnancy. In general, our results indicate that reference gene stability varies between healthy bitches and those with pyometra, and a suite of internal reference genes are recommended to normalize and quantify gene expression accurately.

\section{CONCLUSIONS}

In this study, we evaluated the expression stability of seven candidate reference genes used for normalizing RT-qPCR data in pyometra infected uterine tissue. We identified 
YWHAZ as an appropriate internal reference gene, in both pyometra and healthy samples. We also demonstrated that the reference gene was not expressed stably under all experimental conditions. To conclude, we believe that our study will be beneficial to establish gene expression standards in pyometra, and our data reveals a suite of internal reference genes that could be recommended for accurate normalization and quantification of gene expression in this disease. Finally, our study provides a solid foundation for future studies aimed at understanding various gene functions in pyometra.

\section{Conflicts of interest}

The authors declare no conflict of interest.

\section{ACKNOWLEDGMENTS}

Research supported by the Natural Science Foundation of Tianjin, China (\#11JCZDJC17600) and The Breeding of New Transgenic Livestock and the Research of New Healthy Breeding Technology (\#2011CZZX). We are grateful for the help of the Affiliated Animal Hospital of Tianjin Agricultural University as well as to the Laboratory of Agriculture Analysis of Tianjin Agriculture University for their support.

\section{REFERENCES}

Andersen CL, Jensen JL and Ørntoft TF (2004). Normalization of real-time quantitative reverse transcription-PCR data: a model-based variance estimation approach to identify genes suited for normalization, applied to bladder and colon cancer data sets. Cancer Res. 64: 5245-5250. http://dx.doi.org/10.1158/0008-5472.CAN-04-0496

Arthur GH, Noakes DE and Pearson H (1989). Infertility in the dog and the cat. In: Veterinary reproduction and obstretics (theriogenology) (Arthur GH, ed.). Baillière Tindall, London, 496-500.

Ayers D, Clements DN, Salway F and Day PJ (2007). Expression stability of commonly used reference genes in canine articular connective tissues. BMC Vet. Res. 3: 7.http://dx.doi.org/10.1186/1746-6148-3-7

Bas A, Forsberg G, Hammarström S and Hammarström ML (2004). Utility of the housekeeping genes 18S rRNA, beta-actin and glyceraldehyde-3-phosphate-dehydrogenase for normalization in real-time quantitative reverse transcriptasepolymerase chain reaction analysis of gene expression in human T lymphocytes. Scand. J. Immunol. 59: 566-573. http://dx.doi.org/10.1111/j.0300-9475.2004.01440.x

Brinkhof B, Spee B, Rothuizen J and Penning LC (2006). Development and evaluation of canine reference genes for accurate quantification of gene expression. Anal. Biochem. 356: 36-43.http://dx.doi.org/10.1016/j.ab.2006.06.001

Bustin SA and Mueller R (2005). Real-time reverse transcription PCR (qRT-PCR) and its potential use in clinical diagnosis. Clin. Sci. 109: 365-379.http://dx.doi.org/10.1042/CS20050086

Cankorur-Cetinkaya A, Dereli E, Eraslan S, Karabekmez E, et al. (2012). A novel strategy for selection and validation of reference genes in dynamic multidimensional experimental design in yeast. PLoS One 7: e38351.http://dx.doi. org/10.1371/journal.pone.0038351

Dheda K, Huggett JF, Bustin SA, Johnson MA, et al. (2004). Validation of housekeeping genes for normalizing RNA expression in real-time PCR. Biotechniques 37: 112-114, 116, 118-119.

Dow C (1959). The cystic hyperplasia-pyometra complex in the bitch. J. Comp. Pathol. 69: 237-250. http://dx.doi. org/10.1016/S0368-1742(59)80023-0

Fransson BA and Ragle CA (2003). Canine pyometra: an update on pathogenesis and treatment. Compend. Contin. Educ. Pract. Vet. 25: 602-611.

Frost RA, Mazella J and Tseng L (1993). Insulin-like growth factor binding protein-1 inhibits the mitogenic effect of insulin-like growth factors and progestins in human endometrial stromal cells. Biol. Reprod. 49: 104-111. http:// dx.doi.org/10.1095/biolreprod49.1.104

Fukuda S (2001). Incidence of pyometra in colony-raised beagle dogs. Exp. Anim. 50: 325-329. http://dx.doi.org/10.1538/ expanim. 50.325 
Giudice LC (1994). Growth factors and growth modulators in human uterine endometrium: their potential relevance to reproductive medicine. Fertil. Steril. 61: 1-17.http://dx.doi.org/10.1016/S0015-0282(16)56447-4

Giudice LC, Mark SP and Irwin JC (1998). Paracrine actions of insulin-like growth factors and IGF binding protein-1 in non-pregnant human endometrium and at the decidual-trophoblast interface. J. Reprod. Immunol. 39: 133-148. http:// dx.doi.org/10.1016/S0165-0378(98)00018-7

Glare EM, Divjak M, Bailey MJ and Walters EH (2002). $\beta$-Actin and GAPDH housekeeping gene expression in asthmatic airways is variable and not suitable for normalising mRNA levels. Thorax 57: 765-770. http://dx.doi.org/10.1136/ thorax.57.9.765

Hagman R, Rönnberg E and Pejler G (2009). Canine uterine bacterial infection induces upregulation of proteolysis-related genes and downregulation of homeobox and zinc finger factors. PLoS One 4: e8039. http://dx.doi.org/10.1371/ journal.pone. 0008039

Hardy RM (1980). Cystic endometrial hyperplasia-pyometra complex. In: Current therapy in theriogenology: diagnosis, treatment and prevention of reproductive diseases in animals (Shille VM, ed.). WB Saunders, Philadelphia, 624-630.

Hruz T, Wyss M, Docquier M, Pfaffl MW, et al. (2011). RefGenes: identification of reliable and condition specific reference genes for RT-qPCR data normalization. BMC Genomics 12: 156. http://dx.doi.org/10.1186/1471-2164-12-156

Kubista M, Andrade JM, Bengtsson M, Forootan A, et al. (2006). The real-time polymerase chain reaction. Mol. Aspects Med. 27: 95-125.http://dx.doi.org/10.1016/j.mam.2005.12.007

Lallemant B, Evrard A, Combescure C, Chapuis H, et al. (2009). Reference gene selection for head and neck squamous cell carcinoma gene expression studies. BMC Mol. Biol. 10: 78. http://dx.doi.org/10.1186/1471-2199-10-78

Meller M, Vadachkoria S, Luthy DA and Williams MA (2005). Evaluation of housekeeping genes in placental comparative expression studies. Placenta 26: 601-607.http://dx.doi.org/10.1016/j.placenta.2004.09.009

Miller-Liebl D, Fayrer-Hosken R, Caudle A and Downs M (1994). Reproductive tract diseases that cause infertility in the bitch. Vet. Med. 89: 1047-1054.

Murphy LJ and Ghahary A (1990). Uterine insulin-like growth factor-1: regulation of expression and its role in estrogeninduced uterine proliferation. Endocr. Rev. 11: 443-453. http://dx.doi.org/10.1210/edrv-11-3-443

Murphy LJ, Murphy LC and Friesen HG (1987). Estrogen induces insulin-like growth factor-I expression in the rat uterus. Mol. Endocrinol. 1: 445-450. http://dx.doi.org/10.1210/mend-1-7-445

Nelissen K, Smeets K, Mulder M, Hendriks JJ, et al. (2010). Selection of reference genes for gene expression studies in rat oligodendrocytes using quantitative real time PCR. J. Neurosci. Methods 187: 78-83. http://dx.doi.org/10.1016/j. ineumeth.2009.12.018

Niskanen M and Thrusfield MV (1998). Associations between age, parity, hormonal therapy and breed, and pyometra in Finnish dogs. Vet. Rec. 143: 493-498.http://dx.doi.org/10.1136/vr.143.18.493

Olsvik PA, Lie KK, Jordal AE, Nilsen TO, et al. (2005). Evaluation of potential reference genes in real-time RT-PCR studies of Atlantic salmon. BMC Mol. Biol. 6: 21. http://dx.doi.org/10.1186/1471-2199-6-21

Olvera J and Wool IG (1994). The primary structure of rat ribosomal protein L13. Biochem. Biophys. Res. Commun. 201: 102-107.http://dx.doi.org/10.1006/bbrc.1994.1674

Pfaffl MW, Tichopad A, Prgomet C and Neuvians TP (2004). Determination of stable housekeeping genes, differentially regulated target genes and sample integrity: BestKeeper--Excel-based tool using pair-wise correlations. Biotechnol. Lett. 26: 509-515.http://dx.doi.org/10.1023/B:BILE.0000019559.84305.47

Rubie C, Kempf K, Hans J, Su T, et al. (2005). Housekeeping gene variability in normal and cancerous colorectal, pancreatic, esophageal, gastric and hepatic tissues. Mol. Cell. Probes 19: 101-109. http://dx.doi.org/10.1016/j. mcp.2004.10.001

Sadek KH, Cagampang FR, Bruce KD, Shreeve N, et al. (2012). Variation in stability of housekeeping genes in endometrium of healthy and polycystic ovarian syndrome women. Hum. Reprod. 27: 251-256.http://dx.doi.org/10.1093/humrep/der363

Smith FO (2006). Canine pyometra. Theriogenology 66: 610-612.http://dx.doi.org/10.1016/j.theriogenology.2006.04.023

Stürzenbaum SR and Kille P (2001). Control genes in quantitative molecular biological techniques: the variability of invariance. Comp. Biochem. Physiol. B Biochem. Mol. Biol. 130: 281-289. http://dx.doi.org/10.1016/S1096$\underline{4959(01) 00440-7}$

van Rijn SJ, Gremeaux L, Riemers FM, Brinkhof B, et al. (2012). Identification and characterisation of side population cells in the canine pituitary gland. Vet. J. 192: 476-482.http://dx.doi.org/10.1016/j.tvjl.2011.06.030

van Rijn SJ, Riemers FM, van den Heuvel D, Wolfswinkel J, et al. (2014). Expression stability of reference genes for quantitative RT-PCR of healthy and diseased pituitary tissue samples varies between humans, mice, and dogs. Mol. Neurobiol. 49: 893-899. http://dx.doi.org/10.1007/s12035-013-8567-7

Vandesompele J, de Preter K, Pattyn F, Poppe B, et al. (2002). Accurate normalization of real-time quantitative RT-PCR data by geometric averaging of multiple internal control genes. Genome Biol. 3: research0034. 
Xie F, Sun G, Stiller JW and Zhang B (2011). Genome-wide functional analysis of the cotton transcriptome by creating an integrated EST database. PLoS One 6: e26980.http://dx.doi.org/10.1371/journal.pone.0026980

Ye J, Coulouris G, Zaretskaya I, Cutcutache I, et al. (2012). Primer-BLAST: a tool to design target-specific primers for polymerase chain reaction. BMC Bioinformatics 13: 134.http://dx.doi.org/10.1186/1471-2105-13-134

Zhang X, Ding L and Sandford AJ (2005). Selection of reference genes for gene expression studies in human neutrophils by real-time PCR. BMC Mol. Biol. 6: 4. http://dx.doi.org/10.1186/1471-2199-6-4

Zhong H and Simons JW (1999). Direct comparison of GAPDH, beta-actin, cyclophilin, and 28S rRNA as internal standards for quantifying RNA levels under hypoxia. Biochem. Biophys. Res. Commun. 259: 523-526. http://dx.doi. org/10.1006/bbrc. 1999.0815 